people, burning their homes and their land and using them as forced labour. The inhabitants of this border area can be relatively well-to-do members of the political opposition, or illiterate farmers lacking the most basic education and knowledge about health. Their medical problems are diverse, ranging from the psychological impacts of deprivation, fear and loneliness to the common complaints of infectious diseases and malnutrition to more "Western" illnesses like heart failure and COPD. They come to this clinic because it offers free basic health care to a population that has no official status in their country of refuge. Thailand does not grant refugee status to most migrants, and therefore most of the people fleeing across the border to find work or safety are illegal and have little access to services of any kind. Thus this clinic, now a multi-department quasi-hospital grown out of a small outpatient clinic founded fifteen years ago, serves as a safe haven for many.

Our patient has been listening for many minutes now. As at home, some days are filled with joy and others with sorrow. Today we have seen a 16-yearold woman with malaria; married before menarche at age 12 , she had her first il-

\section{History of medicine}

\section{Unfit to live}

$\mathrm{T}$ he permanent exhibition $W a r$ Against the Inferior: the History of Nazi Medicine in Vienna at the Otto Wagner Hospital of Vienna documents the medical atrocities committed during the Nazi era. Now named after the Secessionist architect Otto Wagner, who proposed the hospital's spacious layout and designed its church, the hospital was called Am Steinhof when it $\hat{\approx}$ opened in 1907. With 34 pavilions and over 2000 beds, it was large and modern for its time. Mounted in 2002, the exhibition reflects Austria's longoverdue official acceptance of responsibility for its actions under Nazi ideology between 1938 and 1945 . legal abortion at age 14 and now has one child. We have seen a mother with severe asthma who, physically incapable of farm work and having left the relative security of the refugee camp, cannot feed her six children. We have also seen a 71-year-old man with a frozen shoulder and a huge, inextinguishable smile.

Wei Lai has finished her history and turns to me. Our patient has had a fever on and off for six months. He has lost much weight. His wife had a similar disease a while ago; as she deteriorated, she left to live with her parents. He has not heard from her since. At that time he was not yet ill. He might never have heard of HIV and tuberculosis. At any rate, he cannot describe these diseases and has no knowledge of their symptomatology, mode of transmission or prognosis. He has no symptoms of tuberculosis anyway, and there is no treatment for HIV/AIDS on the Thai-Burmese border.

The young man climbs down from the examining table and takes his jacket. He gives me a weak smile. Wei Lai will take him to the inpatient department, where he will receive pretest counselling for HIV and will then be tested, should he so wish. If the test result is positive, he will have the option of go- ing home to his family or of remaining at the clinic for support. As he leaves the room, I am floored. Here is a young man dying of ignorance, for how could he protect himself against this disease without knowing that it exists?

I walk out into the sun - the perpetual sun of the Thai-Burma border in mid November. The flowers are blooming and the medics are off to the soccer field as the work day winds to a close. They will enjoy their game and return to play their guitars and sing popular songs into the evening. Teaching goes on in some classrooms, and in another the clinic choir practises for Sunday's service. A new father emerges from from the clinic with a tightly swaddled baby in his arms.

\section{Eva Purkey \\ Department of Family Medicine \\ Queen's University \\ Kingston, Ont.}

The author spent several months in 2002-2003 working at the Mae Tao clinic in Mae Sot, Thailand. Founded by Dr. Cynthia Maung in 1988, the clinic provides essential services to a severely disadvantaged target population of some 150000 in the border area.
The exhibition documents not only what happened at the hospital but also how the doctrine of "racial hygiene" evolved into the Holocaust. From 1938 to 1941 , under the eugenics program "Action T4" (short for the headquarters' street address in Berlin, 4 Tiergartenstrasse), medical authorities selected from medical institutions those "unfit to live" (people with disabilities or mental illness) and those the Nazis dubbed "asocial" (alcoholics, drug addicts, homosexuals and anyone else deemed to be a liability to society). In July and August of 1940 alone, 3200 patients were sent from the Steinhof to Hartheim Castle near Linz to be gassed.
These transports continued until August 1941, when T4 ended because of public protest: for example, parents sent letters to Berlin and demonstrated in

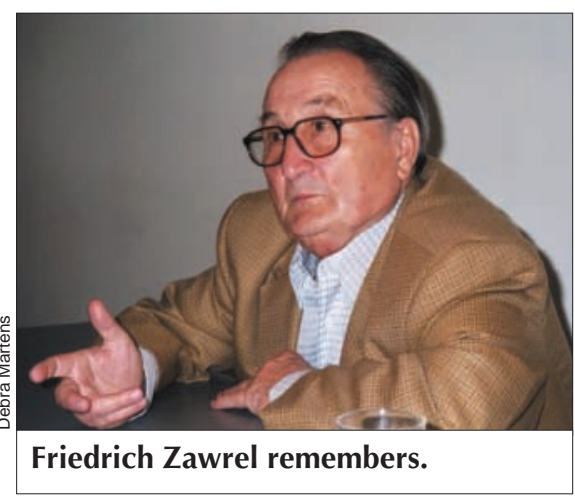


front of hospitals, while nurses and members of the Catholic church spoke out against the killings. By this time over 18000 patients had died at Hartheim. The T4 medical experts were then transferred to work at concentration camps, where they began weeding out the ill and unfit.

From 1940 to 1945 , thirteen pavilions on the grounds of the hospital, emptied by the $\mathrm{T} 4$ murders, were used for a reformatory and a children's clinic, Spiegelgrund. The children at Spiegelgrund included those selected by T4 categories, as well as the children of resistance fighters and communists. In Pavilion 17, doctors conducted experiments on children, particularly those with microcephaly, hydrocephalus, rickets and tuberculosis. They were subjected to painful brain $\mathrm{x}$-rays (which involved withdrawing cerebrospinal fluid and injecting air into the brain cavity, for contrast), exposure to cold and vaccine trials. They were then sent to Pavilion 15 to die of malnutrition and infectious diseases, their resistance further weakened by sedatives. In all, 789 children died; their brains and parts of their spinal cords were removed and preserved for further study.

The director of the children's clinic from 1942 to 1945, neurologist Ernst Illing, was sentenced to death in 1946 for manslaughter. However, Dr. Henrich Gross, the senior doctor on duty in Pavilion 15, was sentenced in 1950 by the Viennese People's Court (a postwar tribunal) to only two years' imprisonment for manslaughter; the Supreme Court of Austria rescinded the verdict

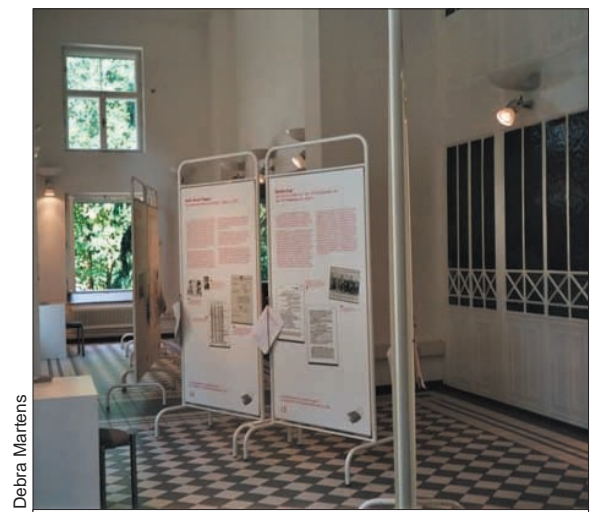

The Unfit to Live installation. in 1951 and retracted charges against Gross. He returned to work at the Steinhof. Despite his questionable past, Gross became a leading neurology specialist, earning such rewards as the directorship of the Ludwig Boltzmann Institute for Clinical Neurobiology, regular work as a court psychiatrist, and even the Austrian Cross of Honour for Science and the Arts

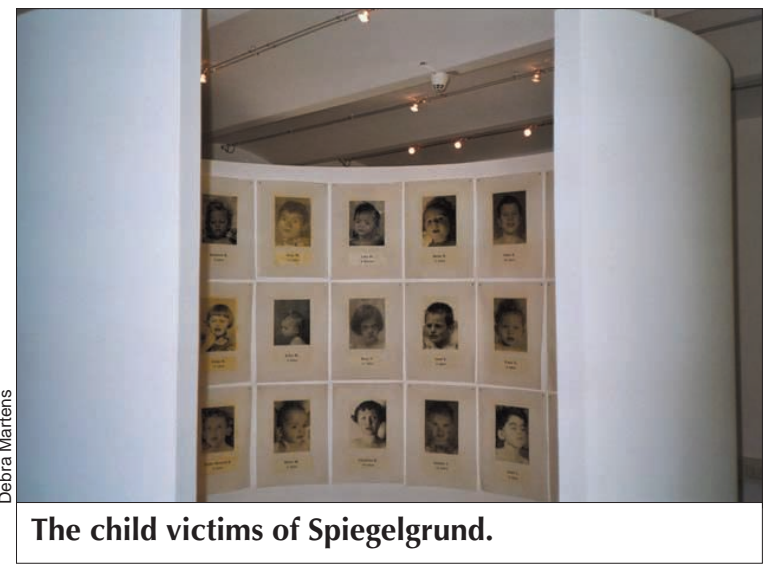
in 1975. Throughout this period (until 1995), Gross used the preserved brains of the children killed at Spiegelgrund as the basis of his research.

In 1976, as court psychiatrist, Gross was assigned the file of one of his former victims, Friedrich Zawrel. During the war, Zawrel had been at Spiegelgrund as the "hardly reformable" son of an alcoholic communist. While there he endured medical testing and nine months of solitary confinement in a bare cell-like room, then escaped with the help of a nurse. After Zawrel contacted the press about Gross, his story was taken up by an organization of doctors who in 1979 exposed Gross's role in the killings of the children at Spiegelgrund. Yet it was not until twenty years later, after new evidence had been found, that Gross was charged with murder by the Viennese District Court. The case never came to trial: charges were dropped in January 2000 on the grounds that Gross, aged 84 , was suffering from dementia.

The story of Dr. Heinrich Gross and Friedrich Zawrel is only one of many told through the exhibition at the Otto Wagner Hospital. The inconclusive nature of its outcome reveals Austria's ambivalence about its Nazi past. This ambivalence extends to the exhibition itself, which suffers from modest and unreliable funding from the city: the display consists only of mounted copies of documents, news clippings, letters and explanatory text, with a few captions in English. There are no videos of survivors, for example, or original documents from the hospital li- brary. Given the poor signage, visitors are unlikely to realize the exhibition is there. Nevertheless, many nurses, teachers and over 250 classes of students have visited the exhibition since it opened in September 2002. Their visits have been enhanced by survivors who come to talk about Spiegelgrund and by lecturers from the Documentation Centre of Austrian Resistance.

During my interview with Friedrich Zawrel, accompanied by Wolfgang Lamsa, one of the exhibition organizers and lecturers, we walked around the grounds of the hospital. Zawrel showed me the window of his cell room in Pavilion 17. I asked, "What do you think when you see that window?" He paused, then smiled and answered, "Joy. I feel joy because I have survived the war, I have survived Hitler, Illing and Gross, I have survived everything." Thanks to survivors such as Zawrel, Austria cannot forget its Nazi past. As Lamsa put it, "To tell the truth now is not a political affair, it is an affair of restoration, of memorial culture." Let's hope the hospital's upcoming centennial in 2007 provides fresh incentive for Vienna to commit itself to this exhibition on Nazi medicine, and to make it more accessible to all visitors.

\section{Debra Martens \\ Writer \\ Vienna, Austria}

More information about the exhibition is available at www.gedenkstaettesteinhof.at/en/ 